\title{
SOCIO-ECONOMIC CHARACTERISTICS OF FISHERIES COMMUNITIES AND ENVIRONMENTALLY FRIENDLY FISHING EQUIPMENT IN BATANG DISTRICT, INDONESIA
}

\author{
Boesono Herry ${ }^{\star}$, Bambang Azis Nur, Husni lqbal Ali \\ Department of Capture Fisheries, Faculty of Fisheries and Marine Sciences, \\ University of Diponegoro, Indonesia \\ *E-mail: herryboesono@gmail.com
}

\begin{abstract}
Capture fisheries development programs in an effort to improve welfare must reflect the effort to preserve their resources. The purpose of this study is to study the characteristics of fishing communities and environmentally friendly fishing equipment in Batang District. This study was conducted for 6 months started in April of 2018. The benefits of this study are as one of the efforts to assist the Government in developing environmentally friendly capture fisheries. This was descriptive analysis research with a case study conducted to the fishing community in Batang district. The analysis used to assess the socio-economic characteristics is a descriptive analysis. The analysis of environmentally friendly fishing equipment, a qualitative analysis was used by scoring based on 9 CCRF criteria. The results of social-economic characteristics of fishing communities indicate that there are socio-economic stratification, patron-client relations, dependence on natural and seasonal resources, hard workers, strong customs and beliefs, but many are low educated. The results of the assessment of environmentally friendly fishing equipment indicate that the most environmentally friendly fishing equipment is bubu with a score of 3.58. Gill net and trammel net are classified as environmentally friendly fishing equipment with a score of 3.23 and 3.12 respectively. Moreover, Arad is environmentally friendly fishing equipment with a score of 1.97 because the operation of arad will damage the bottom of the water and the catch is not selective. Recommendations can be given are the need for counseling on the importance of using environmentally friendly fishing equipment and the government needs to provide direction and assistance to arad fishermen to switch to environmentally friendly fishing equipment.
\end{abstract}

\section{KEY WORDS}

Socio-economic, bubu lipat, gill net, trammel net, arad.

Batang District is located on the northern coast of Central Java Province, it has 5 subdistricts becoming the centers for capture fisheries. There are 4 regions that have representative TPI (Fish Auction Place) namely TPI Klidang Lor in Batang District, TPI West Roban in Tulis Subdistrict, TPI Roban Timur in Subah District, and TPI Celong in Banyuputih District (Nur Hidayah et al., 2018). The number of fishing fleets in Fish Landing Base (PPI) Klidang Lor was 429, West Roban was 160, East Roban was 158, and Celong was 98. (Batang Marine and Fisheries Service, 2018). Fishing equipment is the most important equipment that must be prepared in fishing operations. The types of fishing equipment observed include small bottom trawls, trammel net, gill net and bubu (barrel-like trap). The operation of jaring arad (mini bottomtrawl) and bubu does not require ABK (ship crews) because it can be carried out by fishermen alone, while the operation of gill net and trammel net generally need ABK's assistance (Brandt, 1972; Faik et al., 2018).

Fleet and fishing equipment as the main means of capture fisheries is regulated in such a way that they do not have a negative impact on fisheries resource users and the aquatic environment as well as other users of water services. The use of fishing equipment must pay attention to the balance and minimize negative impacts on other biotas. This is important to consider recalling the loss of biota in the ecosystem structure will affect the overall ecosystem. Errors in anticipating the dynamics of fishing equipment have also caused the 
extinction of fish resources, therefore the use of fisheries resources needs to be done optimally and wisely (Radarwati, 2010).

Non-Environmentally Friendly Fishing (PITRAL) is a fishing activity that tends to be explorative and does not pay attention to conservation rules. Capture fisheries development programs, in an effort to improve welfare, must reflect efforts to preserve their resources (FAO, 1995). This research is important to be carried out to support the development of responsible capture fisheries. Thus, it can guarantee the preservation and sustainability of fish resources. The aim is to determine the characteristics of fishing communities and the status of fishing equipment based on the category of responsible fishing. The research was conducted in Batang District for 6 months started in May 2018.

\section{MATERIALS AND METHODS OF RESEARCH}

The method used in this study is a case study with the object of study collected from 4 TPIs in Batang District. Before carrying out the research, the steps of the research approach were first established. The step of this research approach is determined as a reference or guideline in the implementation in the field so that the data taken is in accordance with the research objectives.

The study of socio-cultural characteristics uses qualitative research methods. The qualitative approach aims to reveal symptoms in a holistic contextual (comprehensive and contextual) through collecting data from key person (respondent). After the data is collected, it was then compiled, analyzed and concluded and finally presented in the form of a research report. With this qualitative approach, it is expected to know, understand, explain and be able to describe the socio-economic characteristics of fishing communities.

The sampling method uses a quota sample of a fisherman using bubu, gill net, trammel net and arad, each of them is 15 persons, including respondents from the fish landing base, so the total was 45 respondents. Primary data obtained from research results are then processed while secondary data is used to support primary data. Secondary data was obtained from Batang and Syahbandar Marine and Fisheries Service.

Analysis of socio-cultural characteristics uses descriptive methods, while the analysis of environmentally friendly fishing equipment uses multi-criteria analysis. The researcher used the criteria for responsible fishing equipment. Fishing equipment units are analyzed based on the category aspects of responsible for 9 criteria. The criteria for responsible fishing equipment are divided into 9 criteria, and each criterion is divided into several subcriteria (Brandt, 1972; FAO, 1995) as follows:

Table 1 - Environmentally Friendly Fishing Equipment Criteria

\begin{tabular}{llll}
\hline No & Criteria & Sub-criteria & Score \\
\hline 1 & Having & Fishing equipment to catch more than three species with different size variations. & 1 \\
& high & Fishing equipment to catch three species with different size variations. & 2 \\
& selectivity & Fishing equipment to catch less than three species with different size variations. & 3 \\
& & Fishing equipment to catch more than three species with different size variations. & 4 \\
\hline 2 & Not & Equipment causes damage to habitat in large areas. & 1 \\
& damaging & Equipment causes damage to habitat in a narrow area. & 2 \\
& habitat & Equipment causes damage to some habitat in a narrow area. & 3 \\
& & Safe equipment for habitat (not damaging habitat). & 4 \\
\hline 3 & Being safe & The use of fishing equipment can result in death for fishermen. & 1 \\
& to & The use of fishing equipment can result in permanent defects in. & 2 \\
& fishermen & The use of fishing equipment can result in temporary health. & 3 \\
\hline 4 & Producing & The use of fishing equipment is safe for fishermen. & 4 \\
& good & Dead and rotten fish. & 1 \\
& quality fish & Fresh dead fish. & 2 \\
& & Living fish & 3 \\
\hline 5 & The & Products have a high chance of causing death. & 4 \\
& product is & Products have the opportunity to cause health problems for. & 1 \\
& not harmful & Products have very little chance for consumer health problems. & 2 \\
& & Safe for consumers. & 3 \\
\hline
\end{tabular}




\begin{tabular}{|c|c|c|c|}
\hline \multicolumn{4}{|c|}{ Table 1 Continue } \\
\hline \multirow[t]{4}{*}{6} & Low by- & By-catch consists of several species not sold in the market. & 1 \\
\hline & catch & By-catch consists of several species and there are species sold. & 2 \\
\hline & & By-catch less than three species and sold in the market. & 3 \\
\hline & & The by-catch is less than three types and is high on the market. & 4 \\
\hline \multirow[t]{4}{*}{7} & $\begin{array}{l}\text { The } \\
\text { minimum }\end{array}$ & $\begin{array}{l}\text { The use of fishing equipment causes the death of all living things and destroys } \\
\text { habitat. }\end{array}$ & 1 \\
\hline & impact on & The use of fishing equipment causes the death of several and destroys habitat. & 2 \\
\hline & biodiversity & $\begin{array}{l}\text { The use of fishing equipment causes the death of several but does not damage } \\
\text { habitat. }\end{array}$ & 3 \\
\hline & & Safe for biodiversity & 4 \\
\hline \multirow[t]{4}{*}{8} & Not & Protected fish are often caught. & 1 \\
\hline & catching & The protected fish is caught several times. & 2 \\
\hline & protected & The protected fish has been caught. & 3 \\
\hline & species. & The protected fish has never been caught. & 4 \\
\hline \multirow[t]{7}{*}{9} & Being & A tool is socially accepted by the community if: (1) Cheap investment, (2) & \\
\hline & socially & economically profitable, (3) in accordance with local culture, (4) in accordance with & \\
\hline & accepted & $\begin{array}{l}\text { existing regulations. Weighting criteria is determined by assessing the reality on the } \\
\text { ground that: }\end{array}$ & \\
\hline & & Fishing equipment fulfills one of the four criteria above. & 1 \\
\hline & & Fishing equipment fulfills two of the four criteria above. & 2 \\
\hline & & Fishing equipment fulfills three of the four criteria above. & 3 \\
\hline & & The fishing equipment fulfills all the criteria above. & 4 \\
\hline
\end{tabular}

Source: Food and Agriculture Organization, 1995.

After all the scores are obtained from the interview, then refresher points are carried out by dividing the total number of scores of respondents by the number of respondents. After the score or value has been obtained, then reference points are made which can be a reference point in determining the ranking. The score or maximum value here is 36 points, while the environmentally friendly fishing equipment category will be divided into 4 categories with the following range of values: $1-\leq 751.75$ very environmentally unfriendly, $>1.75-\leq 2.50$ not environmentally friendly, $>2.50-\leq 3.25$ environmentally friendly, $>3.25-\leq 4.00$ is very environmentally friendly.

\section{RESULTS AND DISCUSSION}

The fishing communities in Batang District live and carry out socio-economic activities related to the resources of the coastal and marine areas in the five coastal areas of Batang District. Coastal communities have certain characteristics that are unique.

Socio-economically and culturally explained that coastal communities have characteristics that are interrelated with each other. As for these characteristics are as follows:

The existence of social stratification. The most prominent social stratification in fishing communities in Batang District is economically stratified and occupationally stratified. Based on the economic status and employment status of fishing communities in Batang, there are three strata groups, consisting of upper strata, namely those who have motorized boats completed with fishing equipment. They are usually known as big (rich) fishermen. Usually they don't go to sea. The fishing operation was handed over to someone else. Rich fishermen frequently also act as collectors. However, there are usually collectors who are not fishermen, so these traders are a separate class. The second strata is those who have boats with outboard motors. In this middle strata, the owner usually goes to sea and leads fishing activities. The participating laborers may exist but are limited and often are family members only. The last strata are the lower strata or fisherman laborers. These laborers include fishermen who do not have fishing facilities, they only work as ABK.

There is a Patron and Client Relationship. The fishing community has a distinctive characteristic in terms of social structure, namely the strong relationship between patrons and fisheries business clients. Patrons usually provide assistance in the form of capital to clients. This is a tactic for patrons to bind clients to their debts so that the business keeps going on. 
Depending on Natural Conditions and the Environment. The conditions of marine natural resources and environmental problems have implications for the socio-economic conditions of coastal communities, especially fishing communities. Environmental damage, especially pollution, because of industrial and domestic wastes can shake the joints of socioeconomic life of coastal communities. For this reason, fisheries development not neglecting the aspects of environmental sustainability are required (Hendriyati et al., 2005).

Dependence on the Market. Dependence on market conditions is caused by the results of their capture that must be sold first before the proceeds of the sale are used to meet the necessities of life. These characteristics have implications for price changes (Farkhan et al., 2018). Changes in the price of fishery products greatly influence the socio-economic conditions of the community.

Having Strong Culture and beliefs. Judging from the aspect of beliefs, the fishing community in Batang District still considers that the sea has the magical power so they still often do sea alms custom. The meaning of the sea alms tradition is a form of offering to the rulers of the sea, which has the meaning to avoid the calamity that occurs when going to sea and as a manifestation of gratitude for the results of the sea. The tradition of sea alms or Nyadran is an annual ritual activity as a form of gratitude for God's blessings for one year. The hope of the fishermen community is to carry out the tradition of sea alms to be able to go fishing safely, comfortably and get abundant sustenance. The cultural tradition of Nyadran which buffers buffalo heads has become an annual agenda and destination for fishing communities in Klidang Lor Village, Batang District. The buffalo head is symbolic because in Javanese "kebo" (buffalo) means ignorance, so we discard ignorant behavior from past to think forward to the challenges ahead.

Hard Worker. Another characteristic of Batang fishing community is the activity of women and children working to earn a living. Women often work as fish traders (retailers), both retailers of fresh fish and processed fish. They also process the fish, both small-scale processing at home to sell themselves or as laborers in fish processing entrepreneurs or other catches. Meanwhile, boys are also involved in fishing activities.

Low Education and Knowledge. Viewed from the education aspect of the fishing community in Batang, most (71\%) are elementary school (SD) graduate, perhaps because the existing education facilities are still very limited. Judged from the knowledge aspect, Batang fishermen's community gets knowledge from their ancestral heritage, it is still rare for them to get knowledge from fishing business training, training on how to use environmentally friendly fishing equipment and by participating in an internship at a large ship.

The results showed that the active fishing equipment in the study area was bubu, gill net, trammel net, and arad. All those fishing equipment are still actively operated by fishermen in Batang district (Faik et al., 2018; Farkhan et al., 2018). The results of the assessment of environmentally friendly fishing equipment indicate that fishing equipment which is very environmentally friendly is a bubu with a score of 3.58. Gill net and trammel net are classified as environmentally friendly fishing equipment with a score of 3.23 and 3.12. While arad is an environmentally friendly fishing equipment (score 1.97).

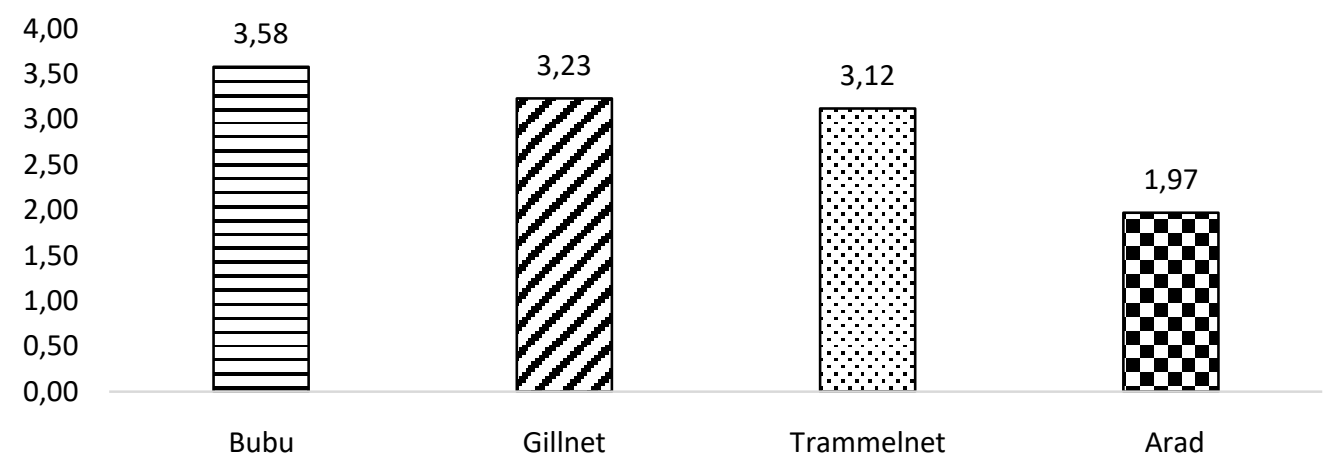

Figure 1 - Graph of the Value of Eco-Friendly Fishing Equipment in Batang District 
According to Sudirman and Mallawa (2004), bubu lipat (folding) is classified as environmentally friendly by fulfilling the criteria of having a high selectivity which is catching fish of one species with a relatively same i.e. crab, safe for fishermen, product yield is relatively safe for consumers and does not harm protected fish. Bubu fulfills several criteria for environmentally friendly fishing equipment based on CCRF with the score obtained is 3.58. This is because bubu lipat meets the criteria for environmentally friendly fishing equipment. Bubu is fishing equipment that has a high selectivity with a score of 3 which indicates that the fishing equipment is less than three species with almost similar size. The catches of bubu lipat are Rajungan (Potrunus Pelagicus), Sembilang Fish (Plotusus Canius), Sebelah Fish (Isettodes Irumei). Bubu lipat is fishing equipment that does not damage habitat with a score of 4 . This is because bubu lipat is operated in muddy or sandy waters, so they are less likely to damage habitat. Bubu lipat, during its operation, does not endanger fishermen, with a score of 4 . The operation of bubu lipat by placing fishing equipment into the waters is done by 2 fishermen. Bubu is operated using a longline system in which the bubu is installed in large quantities and arranged using a rope between one bubu and another. Bubu usually installed with the longline system are associated with snap between the branch straps and the main rope. It is then marked with a floating mark on both ends and equipped with ballast so that the bubu does not move, bubu is installed in the morning, then left, and taken in the afternoon. This eases fishermen to operate bubu so that it is safe and does not endanger fishermen.

The quality of the catches is good with an average score of 4 . The catch of living crab when trapped in the bubu lipat, the high living catch is because the bubu body is made of polyethylene which does not result in the catch being injured and is considered a shelter by the target catch. In addition, the principle of bubu operation trapping the catch does not cause physical defects in the catch that enters the trap. The catch of bubu lipat does not endanger consumers with a score of 4 because the main catch is alive.

By catch consists of three types and is sold in the market. Bubu lipat does not catch large numbers of species so it is safe for biodiversity. During the catch operation, the fisherman can get $30-45 \mathrm{~kg}$ of crab, but the side catch is only $1-2 \mathrm{~kg}$. Bubu does not catch biota protected by law, because the construction of the mouthpiece is flat so that protected biota such as sea turtles are less likely to be caught. In addition, bubu lipat can be socially acceptable and does not conflict with local culture and the existing regulations.

Gill net is included in the environmentally friendly category with a score of 3.23 . This is due to gill net meets several criteria for environmentally friendly fishing equipment based on CCRF. These criteria, among others, as fishing equipment, gill net catches more than three species with a size variation that is more or less the same as the catch selectivity score results by 1 . Gill net can be said selective based on size and less selective by type because it does not only capture the target species. Gill net is said selective based on its size because the mesh size on this fishing equipment is the same for the entire body of the net and also, unlike trammel net which has an inner and outer that causes trammel net is less selective in terms of size.

Gill net fishing equipment is safe for habitats with a score of 4 . This gill net is operated by decreasing the floating sign first, then the rope, and the body of the net. Gill net is operated passively at the bottom of the column of water with muddy habitat so that its use will not damage habitat. The operation of the gill net is safe for fishermen with a score of 4 . The operation of Gill Net does not endanger fishermen. The small weight and size of the fishing equipment make the operation of the gill net easier than other fishing equipment such as arad, so there is no possibility to injure the fisherman.

According to Rusmilyansari (2012), the gill net catch is dominated by fresh dead fish. Gill net catches are dead fish and fresh fish with a score of 3 . The principle of gill net trapping fish makes a small portion of the catch physically damaged in the gills, fins, and scales. Products/fish caught using gill net do not harm consumers and are safe with a score of 4 . The products produced are considered not harmful to consumers because when the fish is sold it is still fresh and the quality is good, so the products produced are safe for consumers. According to Subehi et al., (2017), the by-catch using gill net is a fish that has high economic 
value with not too many species. The by-catch using gill net consists of several species and there are species that are sold on the market with a score of 2. The by-products consist of Patin Fish (Pangasianodon hypophthalmus), Sembilang Fish (Neosilurus sp), Talang Fish (Chorinemus tala), Rajungan (Portunus pelagicus), and Crab (Scylla sp).

The operation of gill net is safe for biodiversity or does not cause death for some species and does not damage the habitat with a score of 4 . Gill net fishing equipment is operated passively so that it is unlikely that this fishing equipment will damage habitat and ecosystems. According to Subehi et al., (2017) during the operation of gill net, fish caught are not from groups of fish or protected biota such as turtles and sharks. Gill net is operated in shallow waters, so protected species such as turtles and sharks have never been caught by this fishing gear. Gill net never catches fish protected by law with a score of 4 . Gill net criteria are socially accepted with a score of 3 . According to fishermen, a gill net is advantageous because this fishing equipment produces catches with good quality and high selling prices.

The results of interviews with respondents using trammel net including in the environmentally friendly category with a score of 3.12. This is because the trammel net meets several criteria for environmentally friendly fishing equipment based on CCRF. Based on the selectivity criteria, trammel net captures more than three species with different size variations with a score of 1 . The main target of the trammel net is shrimp. Trammel net is considered not selective because it captures more than three species with different size variations in one catch.The bag on the trammel net is in the inner net with a size of the net mesh by 1.5 -inch, so that fish of all sizes can be caught in this section.

Trammel net seen from the indicator of damaging habitat or not does show a score of 4. Trammel net is operated by lowering the weight, the body of the net and the float then immersing in the bottom of the water for 30-60 minutes. Respondents claimed to operate trammel net passively in the bottom of the water so that the trammel net does not harm the coral reefs and other basic water environments. The use of trammel net is safe for fishermen with a score of 4 . The safety of fishermen in the fishing process must be considered so will not happen things that are not desirable, so that the fishermen must master the procedures for using each fishing equipment, thus there are no difficulties and even accidents at sea. Based on the interviews with fishermen, trammel net is not dangerous and does not injure fishermen.

Catches from using trammel net are dead fish and fresh fish with a score of 3. Fishermen claim that the white shrimp caught by trammel net is carefully removed from the net because it can affect the selling price. Whereas the bycatch i.e. fish with physical defects such as the injury to the operculum, scales, and fins due to being entangled by a layered net. Fish caught by trammel net is safe to consume with a score of 4 . Fish products resulted from trammel net are considered safe for consumption because the fish is sold in a fresh and good condition. The by-catch using trammel net consists of several species and there are species which are sold on the market with a score of 2 . The by-product of the trammel net consists of several species, namely Dogol Shrimp (Metapenaeus ensis), Tigawaja (Otolithes ruber), Petek (Leioghnatus equllus), Patin (Pangasianodon hypophthalmus), Lundu (Mystus nigriceps), White Snapper (Lates sp), Rajungan (Portunus pelagicus), and Crab (Scylla sp).

The use of trammel net is safe for biodiversity with a score of 4 . The operation of trammel net conducted passively has very little chance of damaging habitat and killing other species. Based on the results of interviews with trammel net fishermen, most of them stated that the trammel net once caught protected fish with a score of 3 . Fish caught are not sharks or turtles, but crabs that are still not suitable for capture with $<10 \mathrm{~cm}$ carapace width. Based on the Regulation of Minister of Maritime Affairs and Fisheries No. 1 of 2015, Rajungan (Portunus pelagicus) catching may be carried out if the carapace width is more than $10 \mathrm{~cm}$. Trammel net fulfills three of the four criteria, socially accepted with a score of 3 , which is economically profitable, in accordance with local culture, and in accordance with existing regulations.

Arad has a score of 1.97 which shows the criteria for fishing equipment not environmentally friendly. Arad is fishing equipment that is categorized as destructive because 
the impact of arad can damage the environment and biological resources. Arad criteria for environmentally friendly are seen from the criteria of fishing equipment selectivity. Arad is fishing equipment having a low selectivity with an average score of 1 , which is to capture more than three species of different sizes. Having been seen from damaging or not the habitat, arad can destroy coral reefs at the bottom of the waters and spawning locations. Arad sweeps the bottom of the waters so that it becomes muddy and can pollute the waters and small corals are damaged. the operation of arad does not endanger fishermen because using fishing aids, with a score of 3 . From the criteria, Arad catches have a poor quality with a score of 2 which indicates that the catch is in a fresh dead state and physically disabled. The products resulted do not endanger consumers. Although the catch is mixed with mud, it is easy to clean and safe for consumers' health with an average score of 4 .

Judged from the by-catch, Arad scores are 1. Arad is not selective and will cause wasted catches to increase because most of the non-target fish caught are then thrown away again in the dead state. Arad's catches are Kuniran Fish (Upenesus Moluccensis), Anchovy (Stolephours Sp), Tigowojo Fish, Squid (Loligo Pealii), Cuttlefish (Sepia Oficinalis) Jerbung Shrimp (Paneus Merguiensis), Dogol Shrimp (Peneaus Monodon), Pufferfish (Tetraodontidae), Tripang (Holothuroidae), Petek Fish (Lelognathus Sp), Crab (Scylla Seirata), Mackerel (Restelliger), White Bawal (Stromateus Cinereus), Lidah Lidah Fish (Cynoglossus Sp), Barracuda (Sphyraena Sp) and Sea Snakes (Hydrophiinae). Arad catches not sold are discarded, such as pufferfish (tetraodontidae), sea snakes (hydrophiinae), jellyfish and tripang.

Having been judged from the impact on biodiversity, Arad's score is 2. Arad is fishing equipment that catches fish in the waters. The operation of arad sweeping the bottom of the waters with a running vessel carried out for 1-2 hours results in small corals being washed away, causing damage to biological resources and even death to some flora and fauna in the waters. Viewed from the aspect of protected fish capture, Arad once received turtles and sharks but returned to the waters. Because fishermen already know that turtles are prohibited and have myths when carrying turtles home will get calamity or bring bad luck, so they are given an average score of 2.

Judged from socially accepted or not, the average score is 2 . Arad is fishing equipment whose price is relatively cheap compared to gill net and trammel net and according to fishermen, it is very profitable because the results are more than those of bubu and gill net. Moreover, Arad can be operated throughout the year, regardless of the season. However, arad is one of the fishing equipment which is prohibited by the government in the Minister of Maritime Affairs and Fisheries Regulation No.71/PERMEN-KP/2016 concerning the Fishing Line and the Placement of Fishing Equipment in the Fisheries Management Areas of the Republic of Indonesia. Arad is fishing equipment that is prohibited from being operated on all fishing routes (Sulistyowati, 2017).

\section{CONCLUSION}

The research results on the socio-economic characteristics of fishing communities in Batang District showed that there were socio-economic stratification, patron-client relations, dependence on natural and seasonal resources, hard workers, strong customs and beliefs, but many were low educated. There are 4 (four) types of fishing equipment in Batang District namely Bubu, Trammel net, Gill net and Small Bottom Trawl (Arad). The fishing equipment which is classified as very environmentally friendly is the bubu with a score of 3.58 . Whereas Gill net and Trammel net are environmentally friendly with scores of 3.23 and 3.12 respectively. Arad is included in non-environmentally friendly fishing equipment with a score of 1.97 .

\section{ACKNOWLEDGEMENTS}

We thank to the Faculty of Fisheries and Marine Sciences of Universitas Diponegoro for providing research assistance in the form of a "Research Grant" in 2018. Our thanks also 
go to Batang Marine and Fisheries Service, the Chair of the fishermen group, the Chair of the TPI in Klidang lor, Celong, and Roban who have helped us in the research process.

\section{REFERENCES}

1. Brandt, A. 1972. Classification of Fishing Gear. In kristjonsson (Ed), Modern Fishing Gear of The World. Fishing News (Books) Ltd. London.

2. Dinas Kelautan and Perikanan Batang. 2018. Data Statistik Perikanan.

3. Faik, K., Shasa, C.,\& Azis, N. 2018. Studi Kasus Penangkapan Ikan Yang Ramah Lingkungan Di Pangkalan Pendaratan Ikan (PPI) Celong, Kabupaten Batang. Indonesian Journal of Fisheries Science and Technology. 14(1), 63-69.

4. FAO. 1995. Code of Conduct for Responsible Fisheries (CCRF). FAO. Rome.

5. Farkhan, N., Sardiyatmo \& Faik, K. 2018. Kelayakan Usaha Penangkapan Ikan Di Tempat Pelelangan Ikan Roban Barat Kabupaten Batang. Journal of Fisheries Resources Utilization Management and Technology. 7(2), 84-88.

6. Hendriati, N., Suwarso., Edvin, A., Khairul, A., Retno, A., Suhendar, I., \& Ikhsan B. 2005. Seasional Variation of Pelagic Fish Catch Around Java. Oceanography. 18(4),112-123.

7. Nur, H., Herry, B., \& Indradi, S. 2017. Analisis Tingkat Efisiensi Tempat Pelelangan Ikan TPI di Kabupaten Batang. Journal of Fisheries Resources Utilization Management and Technology. 6(3), 74-80.

8. Radarwati, S., Mulyono, S., Daniel, R., \& Ari P. 2010. Alokasi Optimum and Wilayah Pengembangan Berbasis Alat Tangkap Potensial Teluk Jakarta. Marine Fisheries. 1(2), 77-86.

9. Rusmilyansari. 2012. Inventarisasi Alat Tangkap Berdasarkan Kategori Status Penangkapan Ikan yang Bertangung Jawab di Perairan Tanah Laut. Fish Scientiae. 2(4), 143-153.

10. Subehi, S., Herry, B., \& Dian, A. 2017. Analisis Alat Tangkap Ramah Lingkungan Berbasis (Code of Conduct for Responsible Fisheries) di TPI Kebung Malang Jepara. Journal of Fisheries Resources Utilization Management and Technology. 6(4), 1-10.

11. Sudirman \& Mallawa, A. 2004. Teknik Penangkapan Ikan. Jakarta: Rineka Cipta.

12. Sulistyowati. 2017. Analisis Tingkat Efisiensi Penangkapan Dengan Jaring Arad di Kabupaten Batang. Jurnal Dinamika Sosial Ekonomi. 6(1), 1-14. 